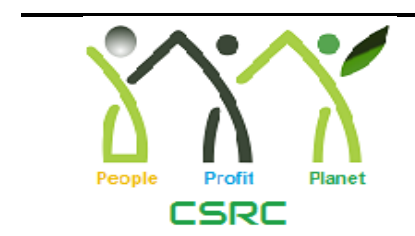

Volume and Issues Obtainable at Center for Sustainability Research and Consultancy

Journal of Business and Social Review in Emerging Economies

ISSN: 2519-089X (E): 2519-0326

Volume 6: No. 3, September 2020

Journal homepage: www.publishing.globalcsrc.org/jbsee

\title{
Organizational Performance and its Affect on Job Satisfaction
}

${ }^{\mathbf{1}}$ Najma Sadiq, ${ }^{\mathbf{2}}$ Ume Laila, ${ }^{\mathbf{3}}$ Tooba Rehan Haqqi, ${ }^{\mathbf{4}}$ Muhammad Ali
${ }^{1}$ Assistant Professor, Department of Mass Communication, School of Social Sciences and Humanities (S3H), National University of Sciences and Technology (NUST), Islamabad, Pakistan, najma.sadiq@s3h.nust.edu.pk

${ }^{2}$ Assistant Professor, Government \& Public Policy, School of Social Sciences and Humanities (S3H), National

University of Sciences and Technology (NUST), Islamabad, Pakistan, dr.umelaila@s3h.nust.edu.pk

${ }^{3}$ Graduate Public Administration, Department of Government \& Public Policy, National University of Sciences and

Technology (NUST), Islamabad, Pakistan, Tooba.bpa16s3h@s3h.nust.edu.pk

${ }^{4}$ NUST Graduate, Department of Economics, School of Social Sciences and Humanities (S3H), National University of Sciences and Technology (NUST), Islamabad, Pakistan, ali.2411@ outlook.com

\begin{tabular}{l} 
ARTICLE DETAILS \\
\hline History \\
Revised format: August 2020 \\
Available Online: September \\
2020 \\
\hline Keywords \\
$\begin{array}{l}\text { Job Satisfaction, Organizational } \\
\text { performance, Organizational } \\
\text { development, } \\
\text { efficiency }\end{array}$
\end{tabular}

JEL Classification

MO, M12

OPEN
ACCESS

\section{ABSTRACT}

This paper aims to find the existing relationship between organizational performance and its effect on the level of job satisfaction. However, given the importance of employee satisfaction on corporate performance, many companies do not pay due attention to this problem due to the lack of understanding among senior management in these companies of its value and influence on the behavior and productivity of employees. In this study we have conducted a thorough research by interpreting results for calculating job satisfaction and finding relationship with organizational performance. This study uses exploratory approach and analyzes data numerically which was obtained by conducting a survey through random sampling.

(C) 2020 Center for Sustainability Research and Consultancy Pakistan under a Creative Commons Attribution-NonCommercial-ShareAlike 4.0

Corresponding author's email address: najma.sadiq@s3h.nust.edu.pk

Recommended citation: Sadiq, N., Laila, U., Haqqi, T. R. \& Ali, M. (2020). Organizational Performance and its Affect on Job Satisfaction. Journal of Business and Social Review in Emerging Economies, 6(3), 1221-1226

\section{Introduction}

In the past ten years, Organizational behavior and business ethics has experienced a lot of revolutions. Ethical issues are the most highlighted drawbacks for any organization, and which by any means have to be dealt with, as these issues are potential enough to portray negative image of organization on employees, in the internal and external markets, on the customers and obviously on other businesses and contracts (S. J. \& D. L., 1990(a)). Traditional research has only focused on the moral grounds of business but now with the change of time and rapid modernization and globalization the trends have changed along with the change in focal of research. Now the focus has shifted from the ethical foundations to the performance factors.

Job satisfaction often leads to loyalty with the firm, and it might not be wrong to say that the biggest predictors of loyalty is the social contract between the worker and the company. In other words, if the worker feels that he does not fulfill his promises that they will become disengaged and less committed, meaning that now we know what behaviors we will look at what triggers them. There are several possible reasons some examples of the personality match between the individual and the company aspects of the psychological contract as we have just 
mentioned, the perceived fairness and justice of the relationship at work and the burden of work- life. As a boss, if you want to encourage employee satisfaction and dedication, you need to recognize these principles as they work to develop those attitudes. One big cause of work satisfaction is perceived honesty by people who believe like their jobs are being consumed or handled poorly seem to have very low job satisfaction and will. Researchers have found that managers seem to have a very bad understanding of employees ' job attitudes and, for many reasons, managers often only believe that staff is happier than they are, and often employees don't feel that they should be truthful with managers. In order to be a successful boss, one must agree to daily surveys to find places of change, which will also offer the worker a sense of confidence that will make them more motivated and, consequently, more fulfilled. In organizational behavior, Job satisfaction stands out as an integral component (Rai \& K. Sinha, April 2002). But as far as the modernized world is concerned where the importance and desire for skilled workers has augmented to a point, job satisfaction may not be a binding and effective concept.

Organizational performance is the actual production of the organization against the planned one. In most of the cases the performance falls short of the intended or set goals. Richard has pointed out three facets onto which performance of any organization can be measured. These facets include; financial productivity, product market performance and shareholder return (Pierre J., Measuring Organizational Performance: Towards Methodological Best Practice , 2009). All these factors contribute in calculating the performance.

With the advent of the organizational development theory, many researchers have started to focus on the development of the organization and are trying harder to provide sufficient recommendations through which the efficiency and production of the organizations are taken to the optimal level (Daft, 2007). Numerous factors have had been considered through which the performance of the organization is monitored. The factors can be of extrinsic or of intrinsic nature. Some organizations focus on the employees in order to enhance performance; some focus on the management style; some focus on the employee-employer relations and much more. Here the point and fact are that the performance depends on the cumulative factors but can also be calculated whole taking only one factor. As far as this study is concerned, the research shall only focus on the satisfaction employees will be having with their jobs and the extent to which the organizational performance is posing either negative or positive effects on the satisfaction level of the employees. In upcoming chapters, we shall provide evidence that the enhanced performance affects the satisfaction level of employees.

\subsection{Limitations of research}

While deciding the variables of research many problems were faced. One of the major problem while deciding the hypothesis was that the factor job satisfaction is a subjective term which majorly depends upon the ambitions and objectives of people who happen to have different thinking and perceiving ability. The subjective nature of word satisfaction made it difficult to meet a common point amongst the employees selected for survey and hence the results obtained might be or might not be different from what the actual situation is.

\section{Literature Review}

Organizational Performance had been the topmost priority of the management researchers for years and the lust has had continued. Many of the researchers have worked In order to find out how organizational performance contributes to the best practices of management. The researchers also suggest that in order to truly measure the performance two things must be monitored rigorously; firstly the nature of performance and secondly the nature of measures on which the performance is being calculated (Pierre J., Timothy M., George S., \& Gerry, 2009). Similarly, in Human Resource Management, relationship between job satisfaction and performance is always on highlight and many researchers have found a true and positive relationship between the said factors. The Canadian credit union believes that the autonomy to express and practice ones knowledge and in the job training does influences the level of satisfaction; enhanced levels of satisfaction increases the employees' performance and in return truly impacts the organization's image at large (Ouedraugo \& Leclerc, 2013).

A study highlights six independent reports on the relationship between compensation and efficiency, and finds that "their proof suggests that compensation is not very closely linked to success in certain organizations that appear to have value in their wage schemes. Studies show that many corporate companies are not doing a very good job of 
connecting pay to results. This inference is somewhat shocking considering the rather repeated arguments made by many corporations that their compensation policies are based on merit. It is especially concerning that compensation does not seem to be linked to success at the administrative level. Such types of reward schemes include benefit share, value share. In terms of profit-sharing, incentives are focused on corporate earnings. There are two possible benefits of the strategy. Next, these will offer an opportunity for workers to behave in the best interests of the company rather than to follow broader targets. Second, by making a percentage of the payout separate from the income of the company, the company can balance its labor expenses more favorably with its willingness to compensate. As a result, there are less fixed wage costs through market downturns (Lawler, 1995).

Existence of organizational performance can easily be justified through the annual audit report of the organizations, subsequently it is very important to communicate these performance evaluations to the shareholders and also to the employees (M. Staw, I. McKechnie, \& M. Puffer, 1983). Not only this through the performance analysis the potential of the agencies or organizations can be determined and obviously communicated (Herman, 1994). In order to evaluate the goals and preferences of the organization it is often seen that what factors it has considered to evaluate its performance. These factors and preferences relationship play an integral part in determining the maturity level of the organization (Seashore \& Yuchtman, 1967).

Job satisfaction has been considered as a vital component to measure the organizational performance. Positive attitudes towards the workplace imposes positive impression on the performance of the firm whereas dissatisfaction portrays negative image of the firm. Intrinsic as well as the extrinsic qualities of the employees must be catered by the managers in order to provide a healthy work setting. It should also be kept in mind that how $b$ creating such a satisfactory environment will lead to better organizational performance (O. \& Omah, 2019). Cognitive ability and intelligence play a part while considering what factors might relate to the satisfaction level. For some employees' fulfillment of certain factors might enhance the level of satisfaction whilst for others there might be a different set of variables (Yoav, 1998). Adopting a right strategy for the organization also effects the performance. While focusing and investigating the financial reports of Pakistani cement and mineral industries it turned out that building a right linkage for strategy and organization positively impacts the performance of that organization (Anwar, Shah, \& Hansu, 2016). If opportunities, motivations and resources provided by the top level authorities to the managers are quite sufficient, they will impact the organizational performance. It is evidential that if managers are not given adequate space an satisfactory environment the stop working hard for the organization thus poising negative image of the organization (C. Hill, 2005).

For long public sector was perceived as one of the most wanted sector in terms of employment butt with the passage of time it has been observed that the level of satisfaction of employees began to deteriorate. Upon investigating the US Federal Government employees' satisfaction level and reasons of quitting it turned out that the ambiguousness nature of organizational goals is the major cause why people have started to leave the federal government (Su, Oct 2014). At the same time, the Korean public organizations are flourishing mainly due to the reason that they have started to focus on the individual factors while making any sort of decisions, and the studies confirm that these highlighted factors does affect the administrative performance, definitely (Kim, April 2005). To arbitrate the fitness of person to job and turnover aims Job Satisfaction and Organizational Commitment play an important role (Chhabra, April 2015). According to the employees of three leading banks of Pakistan, Job satisfaction depends on upon the adopted HR practices by the managers and by the employers. Employees' performance and satisfaction both are greatly affected by the set of HR practices adopted, and this relationship is highly mediated by the extent to which the employees are engaged in day-to-day business and the autonomy they are given to exercise their expertise (Sattar, Ahmad, \& Hassan, Summer 2015).

\section{Research Methodology}

This portion consists of a review of the methodology and essence of the analysis. In addition, a description of the methods used to collect research results, the analysis of these data and the consequences of the test hypotheses has been presented. This chapter further explains the data quality issues associated with the analysis methodology that was chosen. In order to measure the study variables of employee happiness and the extent of impact it poses on corporate performance; it is important to use the quantitative numerical methodological method' which 
is commonly used for deductive models of science. The sample of the current study is predominantly empirical where the key purpose of this examination is to determine the influence of job satisfaction on the extent of organizational performance. The study design is defined as a general strategy for how the researcher can test the study theory, resolve research problems and accomplish the research objectives. Three distinct types of study architecture are commonly used by scholars in the fields of explanatory, analytical and exploratory studies .

The exploratory method of analysis focused on the discovery of new ideas or hypotheses on particular problems based on the findings of the survey, the informative sample used to examine the qualitative knowledge of individuals, cases or circumstances, and the explanatory analysis clarified the relationship between study variables (Dudovsiky, 2018). Therefore, despite to the reasons provided above, we will use exploratory method of research.

The 100 employees of W. E. Apparel Pakistan were the targeted audience and random sampling was used in order to get the surveys filled. The survey was further divided into two parts:

1. First section had the questions related to demographics

2. The second section inquired the employees' satisfaction with the job

The respondents ' answers are tested through "The Five Likert Scale" answer are divided sections as (1 to 5) in following way:

$5=$ highly dissatisfied

$4=$ satisfied

$3=$ neutral

$2=$ satisfied

$1=$ highly satisfied

\section{Research Analysis And Interpretation}

In each factor, the normality test is administered independently to test the most acceptable way to determine the relationship between these variables and the organizational engagement. We used the Kolmogorov - Smirnov interpretation measures to verify the normality of the variables (T. W., 1996).

\subsection{Satisfaction with work}

\begin{tabular}{|l|l|l|}
\hline Questions & $\begin{array}{l}\text { Kolmogorov } \\
\text { Simonov analysis tests }\end{array}$ & $\begin{array}{l}\text { asymp. sig. (2- } \\
\text { tailed)a,b }\end{array}$ \\
\hline I am happy and pleased with my job & 0.797 & 0.000 \\
\hline During my time in office I stay happy & 0.797 & 0.000 \\
\hline During my working hours I don't feel bored & 0.797 & 0.000 \\
\hline My job is suitable to me as compared to others & 0.797 & 0.000 \\
\hline Among all employees around me I feel I stay happiest the most & 0.797 & 0.000 \\
\hline
\end{tabular}

As we can see the Sig.value is precisely equal (0.000), which is less than (0.05), which represents data is not normal. According to the normality test result, the data distribution of the questionnaire areas is "non- normal" and thus non-parametric tests are used. Thus, we used Pearson Correlation in order to evaluate theoretical hypotheses (Schober, Boer, \& Schwarte, May 2018).

H1: There is a positive relationship between work satisfaction and organizational performance

Ho: There is no positive relationship between work satisfaction and organizational performance

\begin{tabular}{|l|l|l|}
\hline & \multicolumn{2}{|l|}{ Organizational Performance } \\
\hline \multirow{3}{*}{$\begin{array}{l}\text { Work } \\
\text { Satisfaction }\end{array}$} & Pearson Correlation & 0.684 \\
\cline { 2 - 3 } & Sig. & 0 \\
\cline { 2 - 3 } & $\mathrm{N}$ & 100 \\
\hline
\end{tabular}


The level of activity between the two variables: happiness/ satisfaction and organizational performance is (.684) at the next level (.000). Consequently, on the basis of these findings, it is evident that there is a significant correlation between these two variables, which suggests that the degree of happiness has had a positive impact on the extent of performance of the organization.

There is a significant relationship between work satisfaction and organizational performance, as supported by the analysis of the significant value. The significant values of "satisfaction with work" is below the threshold of 0.05 i.e. straight zeros, indicating the "non-normal relationship". Similarly, if we view the relationship between work satisfaction and organizational performance in terms of the strength, we can deduce that there is a significant impact. The correlation value being 0.684 indicates that a one unit increase in work satisfaction will resultantly increase organizational performance by $68.4 \%$. Thus, a notable ratio of 1:68.4 highlights the importance of employee's contentment and satisfaction with the organization and the job role. An organization's main objective it to recruit and retain the human capital, in doing so their focus is to attain affective commitment from their side. Work satisfaction can be achieved by numerous ways, that being working environment, work-life balance, motivation, recognition and appreciation, autonomy, engagement and so on. Moreover, a strong and committed workforce leads towards organizational growth much more efficiently, which means the company attains a stronger bottom line and resultantly economies of scale.

Usually, the expectations regarding the motives of study are reflected in the results. But here the figures are highly significant, and it can be devised that the relationship between job satisfaction and organizational performance is highly substantial and stout in nature. Job satisfaction is a vital construct in organizational affairs and that it does affects numerous job related factors and organizational performance. It has been observed that the level of contentment of employees creates favorable environment for the company and in turn boosts up the performance level which enhances the say of the employers in the corporate/ industrial markets.

\section{Conclusion}

It is a fact that employee satisfaction is the most important problem in the company. It's a multi- factorial construction. Employee happiness comprises fundamental elements, energy elements. Basic factors are the minimum criteria which trigger dissatisfaction. Excitement factors improve employee happiness and success factors result in excitement only when success is large. Employee happiness is directly tied to efficiency, which is then tied to company profitability. Employee happiness has a positive effect on corporate efficiency. In comparison, business profitability has fair non-recursive impact on the productivity of workers. Employee happiness plays a major role in maximizing the firm's sustainability and increasing the organizational efficiency of companies and the quality of goods and services. There is an essential partnership between employee and organization. The employee association partnership plays a significant role in the success of each organization. There is a need for innovations. Managers are supposed to establish a job relationship in which actions and decisions can support the interests of the company.

\section{References}

Anwar, J., Shah, S., \& Hansu, S. (2016). BUSINESS STRATEGY AND ORGANIZATIONAL PERFORMANCE: MEASURES AND RELATIONSHIPS. Pakistan Economic and Social Review, 97-122.

Basumallick, C. (2020, May 21). Engagement \& Retention. Retrieved from toolbox: https://www.toolbox.com/hr/engagement-retention/articles

C. Hill, G. (2005). The Effects of Managerial Succession on Organizational Performance. Journal of Public Administration Research and Theory, 585-597.

Chhabra, B. (April 2015). Person - Job Fit: Mediating Role of Job Satisfaction \& Organizational Commitment. Indian Journal of Industrial Relations , 638-651.

Daft, R. L. (2007). Organization Theory and Design . USA: Joe Sabatino.

Dudovsiky, J. (2018). Exploratory Research. In J. Dudovsiky, Writing a Dissertion . Sage Publications . Retrieved from Business Research Methodology .

Herman, L. B. (1994). Organizational Performance and Multiple Constituencies. Public Administration Review, 308- 
312.

Kim, S. (April 2005). Individual-Level Factors and Organizational Performance in Government Organizations. Journal of Public Administration Research and Theory, 245-261.

Lawler, E. E. (1995). The New Pay: A strategic Approach . Compensation and Benefits Review.

M. Staw, B., I. McKechnie, P., \& M. Puffer, S. (1983). The Justification of Organizational Performance. Administrative Science Quarterly, 582-600.

O., O., \& Omah, O. (2019). Impact of Employee Job Satisfaction on Organizational Performance. International Journal of Current Research .

Ouedraugo, A., \& Leclerc, A. (2013). Job Satisfaction and Organizational Performance: Evidence from Canadian Credit Union. Journal of Organizational Culture, Communications and Conflict.

Pierre J., R. (2009). Measuring Organizational Performance: Towards Methodological Best Practice . Journal of Management .

Pierre J., R., Timothy M., D., George S., Y., \& Gerry, J. (2009). Measuring Organizational Performance: Towards Methodological Best Practices . Journal of Managemnt .

Rai, S., \& K. Sinha, A. (April 2002). Job Delight: Beyond Job Satisfaction. Indian Journal of Industrial Relations , 554-571.

S. J., V., \& D. L., D. (1990(a)). Ethical Beliefs of MIS professionals: The Frequency and Oppurtunity for Unetical Behavior. Jurnal of Business Ethics , 63-70.

Sattar, T., Ahmad, K., \& Hassan, S. M. (Summer 2015). ROLE OF HUMAN RESOURCE PRACTICES IN EMPLOYEE PERFORMANCE AND JOB SATISFACTION WITH MEDIATING EFFECT OF EMPLOYEE ENGAGEMENT. Pakistan Economic and Social Review, 81-96.

Schober, P., Boer, C., \& Schwarte, L. A. (May 2018). Correlation Coefficients: Appropriate Use and Interpretation. Anesthesia \& Analgesia, 1763-1768.

Seashore, S. E., \& Yuchtman, E. (1967). Factorial Analysis of Organizational Performance. Administrative Science Quaterly, 377-396.

Su, J. C. (Oct 2014). Organizational Goal Ambiguity and Job Satisfaction in the Public Sector. Journal of Public Administration Research and Theory, 955-981.

T. W., K. (1996). Statistics to Use: Kolmogorov-Smirnov test.

Yoav, G. (1998). Intelligence and Job Satisfaction. The Academy of Management Journal, 526-539. 